\title{
Dynamics of Financing, Governance and Socioeconomic Benefits of Melamchi Water Supply Project in Nepal: Lessons Learnt
}

\author{
Ram Kumar Phuyal ${ }^{1,2 *}$, Madhusudan Bhattarai ${ }^{3}$, Niranjan Devkota ${ }^{4}$ \\ ${ }^{1}$ Centre for Economic Development and Administration (CEDA), Tribhuvan University (T.U.), Kathmandu, Nepal \\ ${ }^{2}$ National Planning Commission, Kathmandu, Nepal \\ ${ }^{3}$ Research Advisory Team, CEDA, Tribhuban University, Kathmandu, Nepal \\ ${ }^{4}$ Research Department, Quest International College, Pokhara University, Lalitpur, Nepal \\ Email: *phuyal_ram5@yahoo.com
}

How to cite this paper: Phuyal, R. K., Bhattarai, M., \& Devkota, N. (2020). Dynamics of Financing, Governance and Socioeconomic Benefits of Melamchi Water Supply Project in Nepal: Lessons Learnt. Modern Economy, 11, 1359-1375.

https://doi.org/10.4236/me.2020.117097

Received: June 7, 2020

Accepted: July 20, 2020

Published: July 23, 2020

Copyright (c) 2020 by author(s) and Scientific Research Publishing Inc. This work is licensed under the Creative Commons Attribution International License (CC BY 4.0).

http://creativecommons.org/licenses/by/4.0/

\begin{abstract}
This study assesses the dynamics of multi-sectorial benefits of a top-flagship project which bears tangible benefits of the project and benefits earned by the beneficiaries through nonrelated water pricing mechanism. The paper is based on content analysis and consultation with the stakeholders concerned and beneficiaries. The result reveals huge tangible benefits from the project; however, poor project governance and institutional weakness in managing the project all contributed to delaying the project by nearly 15 years than its scheduled completion date. This has resulted loses of over tens of millions USD annually only due to missing opportunity to obtain water revenue of transferred water, leaving aside other indirect benefits of water scarce urban households of Kathmandu. The lessons learnt from this project provide valuable information and insight for addressing governances and institutional factors in infrastructural project development and project execution in Nepal and also in other developing countries in the region.
\end{abstract}

\section{Keywords}

Melamchi Water Supply Project, Intersectoral Reallocation of Water, City Water Supply Scheme, Project Financing Complexities, Governance of Water Infrastructure Projects, Public Private Partnership

\section{Introduction}

Drinking water scarcity is a rising phenomenon in a large number of urban centers in South Asia in the last two-three decades (Jacquet et al., 2010). Even in a 
water abundant country like Nepal, due to rapid population growth and increasing urbanization trend, and mismanagement of governance in infrastructure development, the Kathmandu city is facing an acute water shortage in the last three decades (Shrestha et al., 2018; Phuyal et al., 2019). This paper assesses and documents the water scarcity scenario, present status, and timeline on development path and governance factors of a relatively a large scale intersectoral and inter-basin water Transfer project, called as Melamchi Water Transfer Project (MWTP which has been in construction stage in the last 20 years). The MWTP is supposed to supply about 170 Million Litter of water per day (MLD) in the urban areas of Kathmandu, and to provide relief of drinking water scarcity to residents of the capital city [Asian Development Bank (ADB, 2000)]. However, due to institutional weakness, poor management and governance in construction sectors, and lack of coordination across the organizations involved, all have contributed nearly 15 more years of delay in the completion of the project than when it was implemented in 2000, immediately after its financial closure (Clement et al., 2017).

The average 100 million liters per day (MLD) of drinking water supply against 367 MLD was more apparent in 2014 in Kathmandu city. Despite report's claim of $70 \%$ households connecting to a piped water, most receive water intermittently and rarely (Gurung et al., 2016; Phuyal \& Bhattarai, 2017) that almost all households resort to a variety of coping behavior in collecting and receiving water (Pattanayak et al., 2005) with remaining 30\% unnetworked households depending on exhausting or feeble natural resources like tube wells, water spouts, etc. (Bhattarai et al., 2005).

Government's initiation of addressing such alarming level of water demand has come with intersectoral water transfer scheme in bringing water into the city from upstream of Kathmandu valley (Pant et al., 2008; Bhattarai et al., 2002), named Melamchi water diversion and transfer scheme, has three components. Gurung and Bharati (2012) elaborated three stages of project in designing implementing MLD of water supply from Melamchi and other tributaries to Kathmandu valley under the jurisdiction of Melamchi Water Supply Development Board (Phuyal \& Bhattarai, 2017) with an initial proposed date of completion (Pant \& Samad, 2006) and with an aim of fulfilling the objective of overcoming the chronic shortage of portable water to valley residents in sustainable manner (ADB, 2008; Udmale et al., 2016). However, frequent re-designing and re-structuring of the project was further delayed due to 2015 earthquake (Thapa, 2016), which was further postponed to June 2020 (Ching, 2018). Even though the project is designed to serve quality drinking water fulfilling the WHO guidelines, it also would improve the distribution network as set out by the MWPS-subproject, but delay in progress is hindering the health and welfare of $180,000 \mathrm{HHs}$ particularly of the poor (Phuyal \& Bhattarai, 2017) and surprisingly, its completion will improve the basic water and sanitation needs of the consumers in the Kathmandu city, and basic needs of the local environment 
(Ojha et al., 2018). On the other side, the project will provide direct \& indirect benefits to 40,000 people of Melamchi valley, like access to road, better education for children, better health facilities, employment and income from expanded market and indirect benefits may come from the time saved for travel and positive spillover effects on secondary market (ADB, 2000; Phuyal \& Bhattarai, 2017).

This study focuses on financing mechanisms, governances and institutional issues on project implementation, economic benefits of the project, and in an overall socioeconomic framework in the changing dynamics of implementation of the project. The severe shortage of drinking water supply in Kathmandu resembles the problems faced by many other growing urban centers in developing countries. Thus, the lesson learning from the experience of implementing this nature of water transfer project (MWTP) can not only provide valuable information to other such infrastructure project in Nepal, but also to many other countries in Asia, where city water scarcity is increasingly getting a number one problem now.

The paper is organized as follows: after setting the context and background of the study, the second section explains the methodology used in analyzing the facts and figures, the third one discusses on result and the last section offers with authors' conclusion and policy implications of the study.

\section{Methodology}

This study has been prepared using a mixed method of analysis, both quantitative and qualitative. Considering the broad scale of financing of the projects, the following techniques were:

1) Content analysis was done by reviewing past studies on the topic, reviewing project documents and reports from the project-linked agencies and government agencies, and also reviewing studies and grey literature as available from a thorough internet search. Consultation with concerned stakeholders involved in implementing the project.

2) Consultations with beneficiaries, households (limited), bulk water users (hotels), and bulk water suppliers, water tanker owners).

Secondary data was collected to get a larger picture of the study; to break the boundaries and minimize the risk of the low sample size. The advantage of such data is prompt examination of the current policy issues visualization of long-term events (Vartanian, 2010).

Primary information was collected at selected sites in Kathmandu and in upstream communities, using key informant interview notes and Focus Group Discussions. Government officials and scholars were asked about the major milestones in the history of water infrastructure investment in Kathmandu Valley, the major challenges faced in the development of urban water and sanitation services, institutional roles and responsibilities, growth of the private water market and their interaction, access to water and sanitation services to vulnera- 
ble and poor populations and impediments they face in expanding piped network to all residents.

For detailed discussion, the information sought from various stakeholders was compiled, a few representative water supplying vendors were taken as a sample in the survey from supply side (consisting of water source owners, business owners and managers, water tanker owners, truck company owners, and bottled water vendors). Then key informants from the representative areas of Kathmandu Valley were also selected from the demand side. In the case of the water vendors, inventory lists of source owners, tanker truck companies, and drinking water supplying vendors were collected from the central offices of the respective associations of these firms. The source owners' list was verified by visiting the field and checking the owners of various water boreholes. In this study, only the source owners who sold water to tankers other than their own were included.

\section{Result and Discussion}

In this section, first, a brief historical evolution of the Melamchi water transfer scheme is illustrated with time line of major milestones on development pathway of the water transfer project. Then, major component of project financing is provided, including major hurdle in securing financing for the project by the government of Nepal, followed by water demand scenarios in Kathmandu city, and socio-economic analysis and benefits analysis of the water transfer schemes from Melamchi River to the Kathmandu city.

\subsection{A Brief History of the Project}

Looking back, as early as the year 1973, during the preparation of the water supply master plan, the Melamchi River was identified as a potential water source for supplying drinking water needs to the growing population of Kathmandu valley (Devkota, 2001; Pant \& Samad, 2006; Gurung \& Bharati, 2012). Furthermore, Binnie and Partners (1988) studied alternative raw water sources to meet Kathmandu city water needs (Pattanayak et al., 2005). Since then, several studies have been conducted to assess feasibility of Melamchi water transfer project, with details depicted in Annex 1. Now, the $26.5 \mathrm{~km}$ tunnel for transferring water to Kathmandu has already been completed in 2017, but it hasn't reached at the stage of water supply. For this delay in project completion, various reasons are responsible, like lack of institutional reform, natural calamities and exponential growth of water vending markets and so forthy as suggested by Domènech et al. (2013), Thapa (2016), Udmale et al. (2016), Gurung et al. (2017), Phuyal and Bhattarai (2017) and Ching (2018). The development pathway of the Melamchi Water Transfer Project, the dynamics on debate over the water transfer and discussions on various options, including various financing plan of the project in the various periods, are summarized in Annex 1, with time line. 


\subsection{Water Demand Scenario in Kathmandu}

Rapid and unplanned urbanization (Adhikari et al., 2019); outbreak of civil war and migration to valley with the population inhabited beyond carrying capacity (Pandey et al., 2012) resulting in acute water shortage and water supply challenges (Adhikari et al., 2019) are the factors leading to the gap between huge deficit and demand of urban water supply in Kathmandu valley.

The data from various sources show that the water demand in valley has increased from 35.1 MLD in 1998 to 370 MLD in 2015 (Figure 1) as against the water supply of 115 MLD (31.5\%) during the wet season and 69 MLD (19\%) during the dry season (Thapa et al., 2018; Ojha et al., 2018). Water demand at valley is expected to increase to 540 MLD by 2021 (Udmale et al., 2016) and 600 $M^{1} D^{1}$ by 2030 (ADB, 2000). The valley water supply remains almost constant for last seven years (Tamrakar \& Manandhar, 2016) that leads 210 MLD present water supply deficits in valley (Udmale et al., 2016).

More important to note, scarcity and irregularities of water supply, in Kathmandu valley has forced people to look for alternative sources of water supply (Shrestha, 2017). Such water supply irregularities in valley, thus, have led to the privatization of cities water infrastructure including rooftop tanks, drinking water containers and dispensaries (Rest, 2018).

KUKL, an authorized body for valley water supply, covers $90 \%$ of the valley population (Tamrakar \& Manandhar, 2016) and serves approximately 1000 government connections, 171,500 private connections and 1200 public stand post (Pandey et al., 2012). The water demand will be sufficiently met if water from MWSP can be reached to valley and treatment for all necessities in 2021 and no further water shortage after 2025 if MWSP completed in allocated time (Adhikari et al., 2019). But, the frequent shift of the MWSP completion date has made the city people only for dreaming the pipes and lost the hope in the completion of the project altogether (Rest, 2018).

\subsection{Project Financing}

The Melamchi Water Supply Project, approved in 2000 to address the serious shortage of sustainable water sources in Kathmandu Valley, is a comprehensive water supply project started to improve the health and well-being of the people of Kathmandu Valley by diverting water from Melamchi River to Kathmandu Valley (ADB, 2008). With the fulfilling of major objectives required tunnel construction; establishment of bulk distribution system; developing water sources in the valley, even for dry season; improvement of waste water system the original Melamchi project, as envisioned in early 2000, was estimated to cost US\$464 million in 2001, and it was then targeted to be complete in 7 years (Bhattarai et al., 2002). Unfortunately, the work couldn't be completed and it was again revised to US\$355 million in 2014, with additional financing committed by ADB (2014),

${ }^{1}$ The 600 MLD water demands by 2030 includes industrial water use as well (ADB, 2000). 


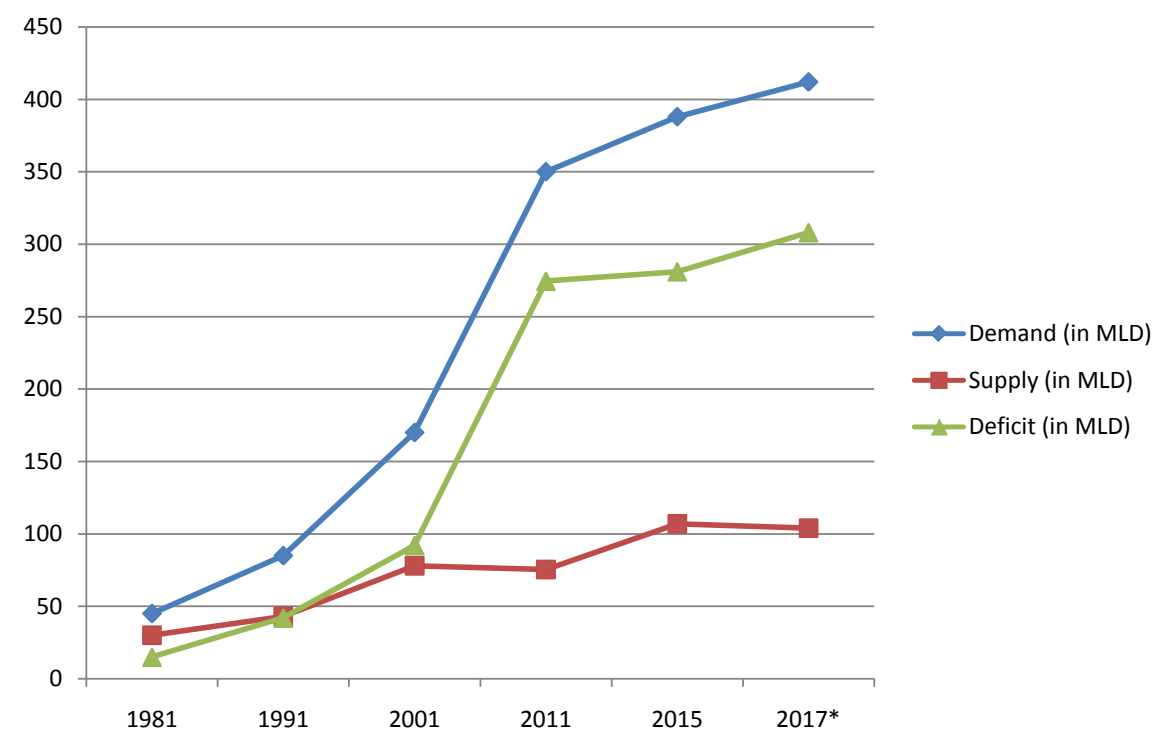

Figure 1. Water demand, supply and deficit (in MLD) in Kathmandu valley. Source: Pandey et al. (2012) and ADB (2015).

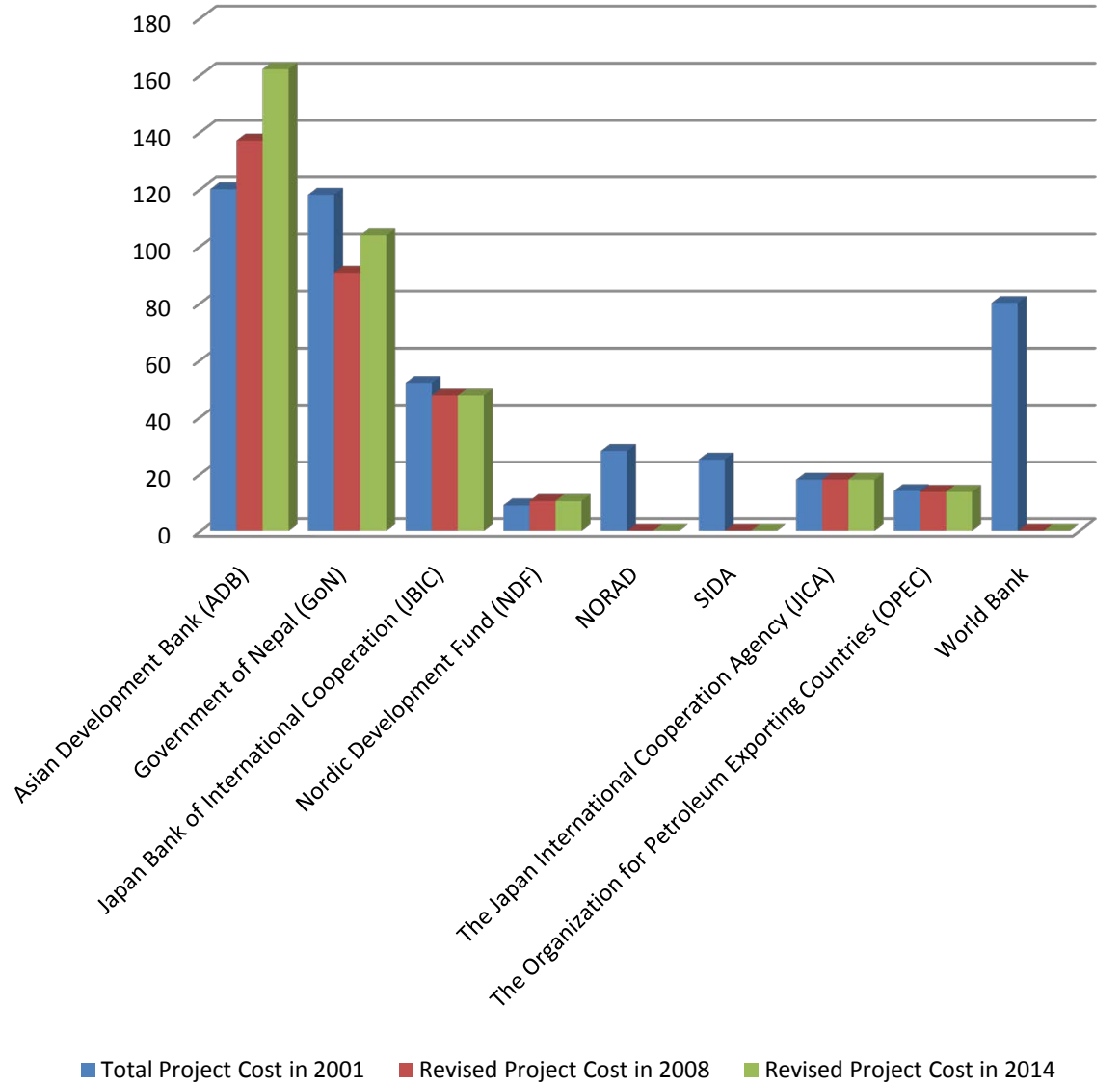

Figure 2. Financing plan of MWS project (US\$ in million). Source: ADB (2000; 2008) and Thapa (2016).

details are also summarized in Figure 2, including financing plan of the project in the various periods. 
Contract approval, contract mobilization, contract termination and re-bidding for construction with different financial agreement and refinancing with increment in cost from 2008 to 2015 has created has created uncertainty and financial irregularities in Melamchi Water Project assignment (ADB, 2015). Project set up did not change even after the restructuring done in 2008, except the cost overrun for tunnel component and related design supervision consultancy of $\$ 38$ million (ADB, 2008). Table 1 presents the overall changes in cost for the different periods.

Despite delays in the project, securing raw water from Melamchi is the least-cost option to meet water demand of growing population of Kathmandu valley. More importantly, in the case of the Melamchi Project, the estimated financial IRR of the overall project including additional financing is 1.25 which is slightly higher than weighted average cost of capital i.e. 1.24 (2015). The project is, thus, technically feasible and economically beneficial.

\subsection{Socio-Economic of Benefits of Water Transfer}

First, we provide a brief description of the major tangible benefits that would be provided by the water transfer project, then we explore the benefit to be obtained by the urban households and several other stakeholders in the city (monetary and non-monetary benefits) through the water transfer scheme, when it is completed soon.

\subsubsection{Analysis of Tangible Benefits}

This section deals with the time saving benefit, water revenue benefits, electricity supply, access to roads in Melamchi, and benefits for the secondary market.

The Time saved: It is estimated that about $70 \%$ of the residents of Kathman$\mathrm{du}$ have a connection to the piped distribution network, but they usually receive poor quality water for only 1 - 2 hours per day (in most of the cases, only 2 - 3

Table 1. Comparison on component-wise cost for the original, restructured projects and current scope.

\begin{tabular}{rlccc}
\hline S.N & \multicolumn{1}{c}{ Items } & $\begin{array}{c}\text { Original Scope 2001 } \\
\text { (US\$ in million) }\end{array}$ & $\begin{array}{c}\text { Restructured Cost in 2008 } \\
\text { (US\$ in million) }\end{array}$ & $\begin{array}{c}\text { Estimated Total Cost in } \\
\text { 2013 (US\$ in million) }\end{array}$ \\
\hline 1 & $\begin{array}{l}\text { 27.5 km diversion tunnel construction, including } \\
\text { construction of access roads and water treatment plant }\end{array}$ & 134.3 & 147.8 & 168.6 \\
2 & $\begin{array}{l}\text { BDS construction, distribution network improvements, } \\
\text { and waste water system improvement }\end{array}$ & 128.1 & 34.4 & 34.4 Completed \\
$3 \quad \begin{array}{l}\text { Kathmandu Valley water source development } \\
\text { (completed before restructuring) }\end{array}$ & 14.1 & 14.1 Completed & 74.1 \\
4 & $\begin{array}{l}\text { Social and environment support and project } \\
\text { implementation support }\end{array}$ & 47.5 & 63.5 & 72.5 \\
5 & Contingencies, tax, and duties $\quad$ Total & 140.0 & 57.5 & 66.1 \\
\hline
\end{tabular}

BDS = bulk distribution system, km = kilometer; Note: Numbers may not sum up precisely because of rounding problem. Source: ADB (2008). Major change in scope: Melamchi Water Supply Project, Manila. 
times per week) (Tamrakar \& Manandhar, 2016). In addition, water is available randomly throughout the day, which implies that one member of the household has to wait all day to collect water when it is available. The benefits of direct consumer surplus as well as positive externalities expected to incur include: saving oftime and cost in fetching, carrying, pumping, purchasing, storing, and treating water; and the reduced risk of health problems. Time saving, which is directly related to the wage of labor, will grow with the increase of GDP.

The Convention of the Inter-American Development Bank assumes that time saving should be valued at 50 percent of the market wage rate for unskilled labor. The minimum wage of unskilled labor in Nepalese Currency is NRs 6200, which converted to US\$, is 62 . (1 US\$ = NRs 100). The overall time saved is equivalent to $\$ 11.5$ million per year ${ }^{2}$.

Water Revenue Benefits. A previous study conducted by ADB estimates that household expenditures on water purifying and collecting water other than tap water supply are more than $\$ 5$ per household per month (ADB, 2015). For households connected to the KUKL system, the median willingness to pay (WTP) is $\$ 9$ per household per month for improved services, i.e., at least $50 \%$ of the sample was willing to pay more than $\$$. The monthly average WTP is $\$ 10.30$ among households with piped connections. For poor households connected to the KUKL system, the mean WTP is $\$ 8$ per household per month.

Based on a survey of a random sample of 1500 households conducted in Kathmandu in 2001 and a follow-up survey in 2014 (Whittington et al., 2017), a mean willingness-to-pay for improved water service was estimated to be $\$ 14$ per month per household. Specifically, respondents were asked whether they would vote for a program that would deliver reliable water supply to their households if it brought a monthly water bill of a specific amount. Another study carried out by Water and Sanitation Program South Asia also concluded that even poor $^{3}$ are ready to pay $\$ 7$ to $\$ 8.5$ per month. This means that people are likely to pay more for household connections if availability and quality of the water is ensured, and that Kathmandu residents would be willing to pay much more once water supply increases.

Saving of Electricity Consumption: Electricity supply in Nepal is very critical and highly unstable. The second benefit is the electricity saved to pump underground water. Currently, an electric pump is required to pump water from ground because of the paucity of surface water supply. The water supply project can result in two hours of electricity saved per day, approximately $1 / 6$ of daily water usage. The 180,000 beneficiary households constitutes roughly $1 / 10$ of all the domestic electricity consumers, and according to the annual report of Nepal's Electricity Commission, the whole domestic consumption amounts to US $\$ 740$ million per annum (Dixit \& Upadhya, 2005). It is thus clear that a saving of ${ }^{2}$ For example: Per person per month time benefit is calculated as 30 days/month $\times 50 \% \times \$ 62$ US $\$ /(22$ working days $\times 8$ working hours/day $)=5.28$ US $\$ /$ person/month. 180,000 households of Kathmandu Valley multiplied by 12 months to per person monthly time benefit gives us the overall time saved benefit $(5.28 \times 180,000 \times 12) 11,404,800$ US\$/year.

${ }^{3}$ I.e. people having less than $\$ 51$ per month income and using wood and cowdung as cooking fuel. 
$740 \times(1 / 6)=105$ million of US\$ annually will be assured from saving on electricity alone.

Access to Road in Melamchi: Access roads, originally built to transport machineries essentials, and other physical components will be available to the locals for transportation needs. This would provide access to markets for the Melamchi Valley inhabitants. To value the benefit incurred, we can see that large part of the benefit involved consists in time saved in transportation for the residents in the remote neighborhood. There are approximately 40,000 people living in areas that can utilize, which access roads to travel to Kathmandu results in approximately 6 hours of time saved per round-trip. Assuming that they make a minimum of 2 trips per year to Kathmandu with the same assumption made for value of time, the benefit is 84,546 US $\$ 4 /$ year annually.

Benefits in Secondary Market. Apart from the benefits and costs mentioned above in the implementation of Melamchi Water Supply project, there are impacts on other sectors, the secondary markets benefits, i.e. labor and land in Melamchi and Kathmandu Valleys. The study made an attempt to monetize benefits that project would bring to the labor market for the local people employed during and after the construction. However, due to time and data resource constraints, we could not figure out the benefit in terms of money. There are a number of local labors recruited for permanent/temporary jobs of projects. Based on the research of Khadka and Khanal (2008) nearly 1020 skilled and semiskilled workers will be working at the Melamchi Diversion Scheme and 1420 jobs would be available every day during the construction of the Bulk Distribution System, Water Treatment Plant and Waste Water Treatment Plant, among which $60 \%$ would be local. That demand would be met by the current unemployed workers staying in Melamchi and Kathmandu Valley, and people from the nearby areas.

Increased business activities resulting from the higher demand for associated services at the construction site would, moreover, create more jobs for the local people. In the labor market, the increase in demand would lead to more labor recruited, and average wage level would go up. Before the project, there were only a few access roads to the site of the Melamchi River and the neighbor areas. There is only one highway between Kathmandu and Melamchi area which is disconnected. With the project introduced and implemented, people in these areas will have $42.2 \mathrm{kms}$ of road built and upgraded, improving their access to the upland and near-river areas along the Melamchi river. Business activities on site and in the two valleys would also create more incentives for people to move and live in there. As land supply can be considered as stable, increase in the demand of land in these sites would, moreover, cause the land price to rise.

\subsubsection{Benefit from Water Supply and Pricing}

As a consequence of the rapid increase in the valley's population in the last two ${ }^{4}$ I.e. 40,000 people $\times 2$ trips/year $\times 6$ hours $\times \$ 62 /(22 \times 8) \times 0.5=89,545.45$ US\$/year annually. 
decades, and low level of public investment in water supply provision and system maintenance, less than 20 percent of the population gets regular supply of piped drinking water (Raina et al., 2018). To overcome the shortage, the long-term plan is to divert water from the Melamchi River outside the valley and deliver it to Kathmandu via a $27.5 \mathrm{~km}$ long tunnel. This project has been long delayed and therefore, currently, the gap is being met primarily by small water enterprises comprising water tankers and bottled water vendors. There are approximately 67 sources of water, 750 tankers supplying the city with water through 210 companies, and 200 drinking water companies in Kathmandu valley (Raina et al., 2018; Ching, 2018).

This private water market could be considered a semi-regulated system because while no legal or institutional mechanism exists to specify the price of the water vended, quantities sold or even quality standards, private vendors have to pay taxes (road and vehicle tax for trucks, VAT for drinking water producers, income tax, etc.) and sources have to get licenses for their boreholes now which are dependent on local communities' approval. There are ad hoc instances of water quality being tested in the valley, but no systematic efforts to ensure the maintenance of quality. As a result, individual companies create their own standards to retain the trust of their customers.

\section{Conclusion, Lessons Learnt and Way Forward}

Several donors (multilateral and bilateral partners) have contributed substantially for development of the Melamchi water transfer project, and developing it to almost at its completion stage. Of total expenditure of US $\$ 317.3$ million, till-mid 2018, the percentage shares of each major donor (partner) financing the project development, as per the restructuring scheme of 2008, are: ADB (43\%), JBIC (15\%), JICA (6\%), NDF (3\%), DFID (4\%), and Government of Nepal (29\%) (ADB, 2008). Despite securing project funding from donors and the Government of Nepal in 2001, due to weak institutions and governance of the implementing agencies in Nepal, the Melamchi project could not be completed by the middle of 2018. The obvious factors in delays on construction by contractors and project management authority are deteriorating security situation and governance system of Nepal in the early 2000s. However, weakness and shortcoming of project management of the public agency responsible for managing the project are not less responsible for delay in completion of the project.

In this context, in the light of detailed financing of Melamchi Water Transfer Project, there are several lessons to be learnt by the government, international donors, NGOs, and other civil societies in Nepal, and in South Asia. Many of the issues discussed in this paper bear relevance for the effective implementation of WASH-related goals and targets of SDGs by the stakeholders involved, such as government, civil societies, private sectors, international donors, and partners involved in financing the water supply projects in the developing world, as listed 
below.

\section{1) Is the Melamchi Project too large for a sectoral ministry? ${ }^{5}$}

In 2014, ADB again approved additional finance to meet the shortfall of fund due to delay in completion. Due to various internal and external factors, such as natural calamities (earthquake) and political turmoil, project implementation is far behind its original target. The Ministry of Water Supply and its subsidiary agency responsible for construction of the Melamchi Project may have had less manpower in the early 2000s to deal with the construction of roads, long tunnels and related infrastructure in the hill and mountain areas. In fact, the Melamchi Project took over 10 years to construct access road to reach the project intake site using the international bidding system, before kick starting on construction of tunnel across the high hill sites. In brief, the inadequate institutional and technical capacity of the Melamchi Project and its line ministry (Ministry of Drinking Water Supply) in dealing with the external partners, including the contractor, is one of the factors in making the long delay in the project completion. The contract for construction of access was terminated several times within the last decades. The delay in construction and extension of the project contract period could be due to rent seeking behavior of both contractors and the $\mathrm{Me}$ lamchi Water authority personnel. Even in the middle of 2018, the Melamchi Project authority granted fund of over 1.25 billion NRs to the project contracting party responsible for building project tunnel.

2) Large projects should address project governance and excessive political interference

The Melamchi project governance is one of the classic cases of mis-governance in infrastructural development in Nepal. In the early stage of the project in 2000, project managers of the Melamchi project hardly stayed for two years, but PMs were changed more frequently along with change in the Water and Sanitation Ministry. In practice, each sectoral Minister of the Ministry of Water Supply at one point wanted to keep his/her pet person as a manager of the Melamchi Project as it was a lucrative project within the ministry eyed by each minister. This led to mis-governance as well as delay in implementation of several project milestones and related activities. The same was the fate of several other large-scale projects in Nepal. Considering the scale of budget and drinking water needs of the capital city, project management and implementation should not be left at the disposal of just internal management of one ministry, or to run the project as per the whim of a sectoral minister. Even the norms and regulations of project implementation plan were changed several times in the last eighteen years. These factors brought uncertainties and lingering, delay in decision-making the project behind the schedule by over twelve years.

\section{3) National Pride Project}

${ }^{5}$ In fact, while consulting on capacity of the Melamchi project in Kathmandu, one of the stakeholder partners said Melamchi project has become like a pumpkin to a Goat. 
With the budget of about US $\$ 317.3$ million, Melamchi project is also one of the top five flagship projects of the Government of Nepal. The project was designed in 1980s to meet the growing water needs of the capital city of Nepal for over 25 years. The Melamchi project is economically and financially very attractive and is also nationally a high priority project. Still it has already taken over 18 years, and is 12 years behind the schedule in completion. This despite the fact, the successive governments of Nepal in the last twenty years has held the project as a high priority national flagship project.

The opportunity cost of delay in completing of Melamchi water project is huge incurring heavy loss to both the public at large and the society. Our preliminary analysis suggests that the maximum social cost of project delay is about US $\$ 0.51$ million per day, which is also the water revenue to be collected by KUKL from the additional 0.17 million cubic water (MLD) supplied by the city water systems, had the Melamchi been completed in time. When we compare the economic value of water with the prevailing water rate the city residents are .paying for tanker-supplied water, which is NRs. 1500 per 5000 liter of water, or NRs 300 for 1000 liters of water (US $\$ 3.00$ per cubic meter of water). In reality, the Melamchi piped supply water will be a higher quality of drinkable standard of water quality as per the KUKL. This means, due to delay in completion of Melamchi project, the city water distribution agency (KUKL) alone is losing a minimum of US\$2.55 million per month at the minimum or over US\$30 million per year. In this simple analysis, we have not taken into account any basic needs of water for drinking and sanitation purposes. When we add all of these tangible and intangible benefits of water uses in the city, the opportunity costs of this delay in completion easily outpaces by many times the financial costs used for project construction. Delayed implementation of this project of national importance raises serious doubts on the quality of the governance and institutional capacity of the project implementation agency.

The irony is that the public agencies responsible for implementing the project work have failed to recover from the lost opportunities and reap other benefits by completing the project in time.

4) Social upliftment program verses Royalty to the upper catchment community

The upper catchment communities in Melamchi project intake sites or above the intake were provided social upliftment program in early 2000 to compensate for the losses that the project has inflicted to the community after diversion of the water out of river. The upper catchment even in 2000 had demanded a royalty of $1 \%$ on the volume of water transferred to the KUKL for city water distribution. Officially, the project has not categorically mentioned ${ }^{6}$ it, however, KUKL is now planning to introduce a benefit sharing scheme by allowing the farmers to pay the water fees by the volume of water used. This issue is addressed/ settled by mutual understanding between government and beneficiaries 
before diverting water from the river.

\section{5) Increasing ownership of project through involvement of stakeholders}

In practice, the over 40,000 households are also lying a claim for a stake on the project by asking for water share from the trading company where the project is listed in Kathmandu's financial market areas (ADB, 2008). This may make it more participatory and inclusive for the citizens and other related stakeholders. Implementation of such innovate ideas in city water supply schemes highlights the importance of such water project which municipalities in Nepal can adapt in policies under their jurisdictions. By offering share to the 40,000 project beneficiaries or other persons in municipality can involve more stakeholders in the project, including more support from additional stakeholders.

6) Separate project management unit (PMU) versus the existing system

Earlier in 2000, for the Melamchi Project, some line agencies and water sector experts in Nepal demanded setting up of a separate PMU, under the office of the Prime Minister, to coordinate the role of the multi-stakeholders related to the development of the infrastructure. However, during the project signing stage in 2001, the Melamchi Water Transfer Project was allocated to the MWS. Calling of introducing the Integrated Corridor Act, the government could not take advantage of the long years of experience of the Ministry of Road and Transport services and other agencies of the government.

7) More research needed on the costs and benefits and distribution of impacts on such water transfers

The level of water market activity is extremely high in Kathmandu and, therefore, water from Melamchi offers good scope for in-depth research on the nature and dynamics of service fees, and financing and governaning of the existing privately-operated tanker supplied water market. Since many growing cities in the developing world exhibit similar issues and problems, a comprehensive document of the lesson learnt from this project diversion analysis could help further in policy formulation on the water utilization, intra and inter-provincial transfer across the sectors in other parts of Nepal, as well as in the cities of other developing countries, where water scarcity is increasingly becoming a major crises for urban livelihoods.

\section{Acknowledgements}

The earlier version of this paper was presented at ADB-Asian Think Tank Development Forum, Colombo, Sri Lanka, on 20-21 September 2017. Authors are thankful to ADB for providing financial support to present the paper at the conference. Authors are also indebted to the conference participants and anonymous reviewers for their insightful suggestions.

\footnotetext{
${ }^{6}$ However, informally, the authors' learnt that the KUKL and the water supplied teams and experts in Ministry of Water Supply is seriously thinking on providing some form of Royalty for the upstream committee, whereas the government authority and KUKL are reluctant to announce it publicly, until the final decision is made by the cabinet ministries.
} 


\section{Conflicts of Interest}

Authors have declared that no conflicting interests exist. The views, conclusions, and recommendations derived here are the narratives concluded by the authors, based on the facts and figures derived in this paper, which do not reflect the official views and perspectives of the organizations where the authors are associated now. This study was carried out in early 2017 A. D. when Dr. Phuyal was working in CEDA, T.U.

\section{References}

ADB (2000). Report and Recommendation of the President to the Board of Directors-Proposed Loan to the Kingdom of Nepal for the Melamchi Water Supply Project. RRP: NEP 31624, Metro Manila: Asian Development Bank.

ADB (2008). Major Change in Scope and Implementation Arrangements-Nepal: Melamchi Water Supply Project and Kathmandu Valley Water Services Sector Development program. RRP. 31624 and 36609, Manila: Asian Development Bank.

ADB (2014). Report and Recommendation of the President to the Board of Directors on a Proposed Loan for Additional Financing Nepal: Melamchi Water Supply Project. RRP: NEP 31624, Metro Manila: Asian Development Bank.

ADB (2015). Report and Recommendation of the President to the Board of Directors on a Proposed Loan for Additional Financing Nepal: Kathmandu Valley Water Supply Improvement Project. RPP: NEP 34304-044, Manila: Asian Development Bank.

Adhikari, B. R., Shrestha, S. D., \& Shakya, N. M. (2019). Future Urban Water Crisis in Mountain Regions: Example of Kathmandu Valley, Nepal. In B. Ray, \& R. Shaw (Eds.), Urban Drought (pp. 169-182). Singapore: Springer. https://doi.org/10.1007/978-981-10-8947-3 11

Bhattarai, M., Pant, D., \& Molden, D. (2005). Socio-Economics and Hydrological Impacts of Melamchi Intersectoral and Interbasin Water Transfer Project, Nepal. Water Policy, 7, 163-180. https://doi.org/10.2166/wp.2005.0011

Bhattarai, M., Pant, D., Mishra, V. S., Devkota, H., Pun, S., Kayastha, R. N., \& Molden, D. (2002). Integrated Development and Management of Water Resources for Productive and Equitable Use in the Indrawati River Basin, Nepal (Vol. 41). IWMI.

Binnie and Partners (1988). Water Supply for Kathmandu-Lalitpur from Outside the Valley-Pre-Feasibility Study, Final Report. August 1998. http://bit.ly/2p7XY1u

Ching, L. (2018). The Paradox of Social Resilience: Explaining Delays in Water Infrastructure Provision in Kathmandu. Water Alternatives, 11, 61-85.

Clement, F., Suhardiman, D., \& Bharati, L. (2017). IWRM Discourses, Institutional Holy Grail and Water Justice in Nepal. Water Alternatives, 10, 870-877.

Devkota, H. (2001). Process Documentation Research of Melamchi Water Supply Project: A Case of Inter-Basin Water Diversion in Nepal. In R. N. Kayastha, U. Parajuli, D. Pant, \& C. Sharma (Eds.), Integrated Development and Management of Water Resources: A Case of Indrawati River Basin, Nepal (pp. 70-89). Proceedings of a Workshop held in Kathmandu, Nepal, 25 April 2001, organized by Water and Energy Commission Secretariat (WECS) and IWMI.

Dixit, A., \& Upadhya, M. (2005). Augmenting Groundwater in Kathmandu Valley: Challenges and Possibilities (pp. 5-40). Nepal Water Conservation Foundation.

Domènech, L., March, H., \& Saurí, D. (2013). Contesting Large-Scale Water Supply 
Projects at Both Ends of the Pipe in Kathmandu and Melamchi Valleys, Nepal. Geoforum, 47, 22-31. https://doi.org/10.1016/j.geoforum.2013.02.002

Gurung, P., \& Bharati, L. (2012). Downstream Impacts of the Melamchi Inter-Basin Water Transfer Plan (MIWTP) under Current and Future Climate Change Projections. Hydro Nepal: Journal of Water, Energy and Environment, 11, 23-29. https://doi.org/10.3126/hn.v11i1.7199

Gurung, Y., Zhao, J., Kumar KC, B., Wu, X., Suwal, B., \& Whittington, D. (2017). The Costs of Delay in Infrastructure Investments: A Comparison of 2001 and 2014 Household Water Supply Coping Costs in the Kathmandu Valley, Nepal. Water Resources Research, 53, 7078-7102. https://doi.org/10.1002/2016WR019529

Jacquet, P., Pachauri, R. K., \& Tubiana, L. (Eds.) (2010). Cities: Steering towards Sustainability. The Energy and Resources Institute (TERI).

Khadka, R. B., \& Khanal, A. B. (2008). Environmental Management Plan (EMP) for Melamchi Water Supply Project, Nepal. Environmental Monitoring and Assessment, 146, 225-234. https://doi.org/10.1007/s10661-007-0074-8

Ojha, R., Thapa, B. R., Shrestha, S., Shindo, J., Ishidaira, H., \& Kazama, F. (2018). Water Price Optimization after the Melamchi Water Supply Project: Ensuring Affordability and Equitability for Consumer's Water Use and Sustainability for Utilities. Water, 10, 249. https://doi.org/10.3390/w10030249

Pandey, V. P., Shrestha, S., \& Kazama, F. (2012). Groundwater in the Kathmandu Valley: Development Dynamics, Consequences and Prospects for Sustainable Management. European Water, 37, 3-14.

Pant, D., \& Samad, M. (2006). Stakeholder Consultation and Water Governance: Lessons from the Melamchi Water Transfer Project in Nepal. In CPWF DSS Workshop (pp. 23-26). Paper prepared for CPWF DSS Workshop, Ethiopia, 23-26 January 2006.

Pant, D., Bhattarai, M., \& Basnet, G. (2008). Implications of Bulk Water Transfer on Local Water Management Institutions: A Case Study of the Melamchi Water Supply Project in Nepal (No. 78). International Food Policy Research Institute (IFPRI).

Pattanayak, S. K., Yang, J. C., Whittington, D., \& Bal Kumar, K. C. (2005). Coping with Unreliable Public Water Supplies: Averting Expenditures by Households in Kathmandu, Nepal. Water Resources Research, 41, W02012. https://doi.org/10.1029/2003WR002443

Phuyal, R. K., \& Bhattarai, M. (2017). Dynamics of Financing and Governance of the Melamchi Water Supply Project in Kathmandu. ADB-Asian Think Tank Development Forum: Promoting Sustainable Urbanization in Asia and the Pacific, Asian Development Bank, Colombo, Sri Lanka, 20-21 September 2017.

Phuyal, R. K., Maharjan, R., Maharjan, R., \& Devkota, N. (2019). Assessments of Drinking Water Supply Quality at Squatter and Indigenous Settlements of Bagmati River Corridors in Kathmandu. Scientific Research and Essays, 14, 53-67. https://doi.org/10.5897/SRE2016.6474

Raina, A., Gurung, Y., \& Suwal, B. (2018). Equity Impacts of Informal Private Water Markets: Case of Kathmandu Valley. Water Policy, 22, 189-204. https://doi.org/10.2166/wp.2018.138

Rest, M. (2018). Dreaming of Pipes: Kathmandu's Long-Delayed Melamchi Water Supply Project. Environment and Planning C: Politics and Space, 37, 1198-1216.

Shrestha, K. B., Thapa, B. R., Aihara, Y., Shrestha, S., Bhattarai, A. P., Bista, N. et al. (2018). Hidden Cost of Drinking Water Treatment and Its Relation with Socioeconomic Status in Nepalese Urban Context. Water, 10, 607. 
https://doi.org/10.3390/w10050607

Shrestha, S. (2017). The Contested Common Pool Resource: Ground Water Use in Urban Kathmandu, Nepal. Geographical Journal of Nepal, 10, 153-166.

https://doi.org/10.3126/gjn.v10i0.17396

Tamrakar, N. K., \& Manandhar, K. C. (2016). Institutional Capacity Assessment of KUKL. Kathmandu: Ministry of Urban Development (MOUD) \& Japan International Cooperation Agency (JICA).

Thapa, B., Ishidaira, H., Pandey, V., Bhandari, T., \& Shakya, N. (2018). Evaluation of Water Security in Kathmandu Valley before and after Water Transfer from Another Basin. Water, 10, 224. https://doi.org/10.3390/w10020224

Thapa, G. (2016). No Water at the End of Melamchi Tunnel. The Kathmandu Post, 21 March 2016. http://bit.ly/2p05PTo

Udmale, P., Ishidaira, H., Thapa, B. R., \& Shakya, N. M. (2016). The Status of Domestic Water Demand: Supply Deficit in the Kathmandu Valley, Nepal. Water, 8, 196. https://doi.org/10.3390/w8050196

Vartanian, T. P. (2010). Secondary Data Analysis: Pocket Guide to Social Work Research Methods. Oxford: Oxford University Press.

Whittington, D., Adamowicz, W., \& Lloyd-Smith, P. (2017). Asking Willingness-to-Accept Questions in Stated Preference Surveys: A Review and Research Agenda. Annual Review of Resource Economics, 9, 317-336.

https://doi.org/10.1146/annurev-resource-121416-125602 


\section{Annex}

Table A1. A historical time lines and development pathway of the Melamchi water project, Nepal.

\begin{tabular}{cl}
\hline Year & \multicolumn{1}{c}{ Major Mile stones on Development Pathways of Melamchi Project } \\
\hline $1973 \quad \begin{array}{l}\text { For the first time water transfer from Melamchi river was identified as a possible agenda to meet the growing water demands of } \\
\text { Kathmandu Valley. }\end{array}$ \\
Few Studies were carried out on Melamchi water transfer scheme, as one of few alternate options to resolve growing water needs of \\
Kathmandu city. Water transfer with hydropower plant (higher dam) scheme was discussed by development partners in Nepal \\
UNDP, ADB, and WB. No consensus reached on exact modality of its construction till late 1990s. To install hydropower plan in \\
upstream of Melamchi or not was a long -held debate attached with this Melamchi water transfer project in early 1990.
\end{tabular}

Govt. of Nepal started feasibility study for a project with transferring of water from the upstream located Melamchi River to Kathmandu city, keeping open also for other alternate options for supplying water in the city

Prime Minister of Nepal then, late K P Bhattarai, announced in a public forum that water from Melamchi Project (River) will be brought to meet the drinking water needs of Kathmandu city.

1992 Australian based Consulting Company did feasibility study of Melamchi water transfer project.

1995 Melamchi water supply ltd a public company, was established by Govt. of Nepal to manage water supply systems in Kathmandu city

Melamchi Development Committee was established by Govt. of Nepal to secure funding and manage the water transfer scheme between Melamchi river and Kathmandu.

ADB-led consortium secures full funding of the project and approved by the government of Nepal to initiate the project with creation of Melamchi Water Transfer Project (MWTP), with a target of completion of the project by 2007.

Privatization of city water system attached as a precondition for financing becomes source of contention among government agencies, NGOs, civil societies, and external donors (WB, ADB, and other partners). Full privatization is regarded as difficult by the government.

Withdrawal of World Bank (due to failure to appoint a foreign private operator to manage water supply).

Withdrawal of funding to the Melamchi project by Norwegian Agency for International Cooperation (NORAD) and Swedish International Development Cooperation Agency (SIDA) due to failure to appoint a foreign private operator to manage water supply.

Kathmandu Upatyaka Khanepani Limited (KUKL) is established PPP to manage city water supply system (under precondition for full of financing).

2008 Restructuring of project cost done. The project cost estimates reduced to 317 million US\$ from 464 million US\$.

Tunnel construction contract awarded to China Railway 15 Bureau Group Corporation (CR15G) on 19 February 2009 for 4.5 years under contract of US\$ 66 million. Local groups padlock project office, which was then unlocked in January 2010.

MWSDB terminates the contract with CR15G on 25 September 2012. Physical progress (i.e. tunnel excavation) is only $22 \%$ (6.3 km out of $27.5 \mathrm{~km})$.

New contract awarded to an Italic company, Cooperativa Muratorie Cementisti (CMC) di Ravenna, in July 2013 with contract of 98.7 million US\$, resulting in an estimated cost overrun of 32.7 million US\$.

2014 Cost again re-estimated to 355 million US\$ with additional financing committed by ADB.

2015 Earthquake of 8 rector scale pushes back work to 2020.

2016 City water pipe replacement work starts replacement/rehabilitation (some pipe lines are more than 50 years old).

2016 Second extension was given in summer of 2016 for completion data for the project, which is then pushed back to June of 2020.

2016 Italian Company (CMS) filed a case at International Arbitration Court for variation order of the Melamchi Water Project (specially tunnel construction work)

A major break through on the project as construction of $26 \mathrm{~km}$ tunnel was completed, and remaining of only limning and finishing task of the tunnel.

On 16 December 2018, the CMS company officials submitted a letter to Melamchi Project and the government about its decision to discontinue with the Melamchi water project, due to liquidity problems in its parent company in Italy, and with lack of fund for day-to-day work at the project site. The project status is in limbo again at the end of 2018, until a new negotiation takes place between the CMS and the Melamchi project authority in early 2019.

June 2020 Expected date of completion (as of Aug 2016). 